\title{
Vitamin D deficiency in cord plasma from multiethnic subjects living in the tropics
}

\author{
Brunhild M. Halm, MD, PhDa,b,c, Jennifer F. Lai, $\mathrm{MS}^{\mathrm{c}}$, Ian Pagano, $\mathrm{PhD}^{\mathrm{c}}$, William Cooney, \\ BA $^{c}$, Reni A. Soon, MD ${ }^{a, b}$, and Adrian A. Franke, PhD $^{c}$ \\ aKapi'olani Medical Center for Women and Children, Honolulu, Hawai'i \\ bUniversity of Hawai'i, John A Burns School of Medicine, Honolulu, Hawai'i \\ 'University of Hawai'i Cancer Center, Honolulu, Hawai'i
}

\section{Abstract}

\begin{abstract}
Background-Vitamin D deficiency is commonly reported in high latitude areas and in dark pigmented individuals. However, nothing is known about vitamin D in cord blood from multiethnic subjects living in the tropics.
\end{abstract}

\begin{abstract}
Objective-Our study objective was to determine the prevalence of vitamin D deficiency in summer and winter in cord blood from multiethnic individuals in Hawai'i where sufficient sun irradiance occurs year-round for cutaneous vitamin D production.
\end{abstract}

Methods-25-hydroxyvitamin D (25(OH)D) levels were quantified by enzyme-immunoassay in 100 cord plasma samples from apparently healthy full term newborns and their mothers.

Stratification was performed by birth season and ethnicity.

Results-Mean 25(OH)D levels were $24.5 \mathrm{ng} / \mathrm{mL}(9.1-68.3 \mathrm{ng} / \mathrm{mL})$. Overall, $28 \%$ of samples were Vitamin D deficient ( $<20 \mathrm{ng} / \mathrm{mL}$ ) and $50 \%$ were insufficient $(20-30 \mathrm{ng} / \mathrm{mL})$. 25(OH)D levels $(\mathrm{ng} / \mathrm{mL})$ were highest in Caucasians $(30.5, \mathrm{n}=19)$ then Asians $(25.1, \mathrm{n}=43)$, Hispanics $(21.5, \mathrm{n}=3)$, Pacific Islanders (20.0, $\mathrm{n}=25)$, and African Americans $(19.6, \mathrm{n}=2)$. Differences among groups were significant $(\mathrm{p}=0.008)$. Cord plasmas from summer versus winter were higher overall $(\mathrm{p}=0.001)$ and among Asians $(\mathrm{p}=0.0003)$. Seasonal changes were correlated with sun irradiance overall ( $\mathrm{r}=0.43, \mathrm{p}=0.0001)$, among Caucasians $(\mathrm{r}=0.45, \mathrm{p}=0.05)$, and among Asians $(\mathrm{r}=0.45$, $\mathrm{p}=0.0001)$.

Conclusion-Our results suggest that prenatal supplement recommendations of $400 \mathrm{IU}$ vitamin $\mathrm{D} /$ day does not protect against vitamin D deficiency, even in subjects living in the tropics where ample sun irradiance exists for cutaneous vitamin D synthesis. The high prevalence of vitamin D deficiency we observed emphasizes the necessity for regular 25(OH)D monitoring, particularly during pregnancy and lactation, in dark pigmented individuals, and during winter months.

\section{Keywords}

vitamin D insufficiency; seasonal variation; cord blood; Hawaii

Address for reprint request and corresponding author: Adrian A. Franke, PhD University of Hawaii Cancer Center 1236 Lauhala Street Honolulu, HI 96813 Phone: (808) 586-3008 Fax: (808) 586-3009 adrian@ cc.hawaii.edu.

Financial Disclosure and Conflict of Interest: All authors state that they have no conflict of interest. 


\section{INTRODUCTION}

The relevance of vitamin D for maintaining health throughout life is supported by its vital involvement in controlling approximately $3 \%$ of the human genome in addition to affecting numerous other essential functions and conditions such as calcium and bone metabolism, rheumatoid arthritis, infections, multiple sclerosis, type 1 and 2 diabetes mellitus, autoimmune disease, cardiovascular disease, Crohn's disease, and many cancers [1-8].

Poor vitamin D status has been shown to be more prevalent during pregnancy [9] and is a major risk factor for preeclampsia, delivery via cesarean section in pregnant women, and for infant rickets, respiratory infections, wheezing, diabetes, and possibly schizophrenia and autism in early life and childhood [10-16]. In utero, the fetus is completely dependent on the mother for vitamin D with the vitamin D status of the fetus closely related to that of the mother [17]. Recent studies have shown 25-dihydroxy vitamin D (25(OH)D) levels in cord blood to correlate well with those in maternal blood [18-20]. Thus, during pregnancy, the maintenance of sufficient $25(\mathrm{OH}) \mathrm{D}$ levels remains of utmost importance.

Several studies in adults have reported low vitamin D status among individuals with dark skin pigmentation [21], in people living at high latitudes [22], and during winter months [18, 23-26], while a few studies using umbilical cord blood have found widespread vitamin D insufficiency at latitudes 24 to $67^{\circ}[18,19,27,28]$. However, the prevalence of vitamin D deficiency and insufficiency in cord blood or venous blood from multiethnic individuals living in a tropical climate is not known.

Our study objectives were to determine vitamin D status in cord blood from a convenience sample of 100 subjects and to examine whether cord blood vitamin D status varies during different seasons and within different ethnic groups in Honolulu, Hawai'i, a low-latitude $\left(21^{\circ} \mathrm{N}\right.$ latitude) tropical location with ample year-round sun exposure and extensive ethnic diversity.

\section{PATIENTS AND METHODS}

\section{Sample Collection}

This study was part of a prospective investigation on antenatal seafood exposure and neurodevelopmental outcomes in infants. Healthy pregnant women admitted for delivery to Kapi'olani Medical Center for Women and Children in Honolulu, Hawai'i (island of Oahu) between June 2010 and March 2011 were assessed for study eligibility. Patients were considered eligible if they were between 18 and 45 years old, pregnant with a singleton live fetus and gestational age $\geq 37$ weeks. A total of 107 cord blood samples were collected after cord clamping but only 100 samples were used in the final analysis after excluding mothers who could not provide consent or whose infants were not able to be examined prior to discharge. Routine newborn examinations were performed immediately after birth in addition to a Ballard scale and a Neonatal Intensive Care Unit Network Neurobehavioral Scale exam. Exclusion criteria included reported tobacco, alcohol, or illicit drug use; English illiteracy; pregnancy with multiple gestation; women who wanted to take home their placentas; women with diabetes, hypertension or other chronic diseases; and women pregnant with a fetus with growth restriction or any known congenital anomalies.

After delivery, approximately $20 \mathrm{~mL}$ of whole blood from the umbilical cord was collected into EDTA tubes and processed within two hours. Personal and demographic data were obtained through questionnaire. Infant birth weight, APGAR scores, head circumference, length, gestational age, sex, date of birth, and maternal daily intake of 400 IU Vitamin D supplementation were also documented. The Institutional Review Board at Kapi'olani 
Medical Center for Women and Children and the Western IRB approved this study and all participants signed a consent form.

Solar ground radiation data (or global horizontal irradiance (GHI), the sum of direct normal irradiance, diffuse horizontal irradiance, and the negligible ground-reflected radiation) were retrieved online from the National Renewable Energy Laboratory (NREL) website (http://www.nrel.gov/midc/kalaeloa_oahu/). The data were recorded at Kalaeloa, Hawai'i (island of Oahu, latitude $21.3^{\circ} \mathrm{N}$, longitude $158.1^{\circ} \mathrm{W}$, altitude $11 \mathrm{~m}$ AMSL) by a Rotating Shadowband Radiometer that uses a silicon-based photodiode pyranometer. Averaged 24-hour readings of total solar radiation $\left(\mathrm{W} / \mathrm{m}^{2}\right)$ for the 17 days prior to and including the birthdate were used to calculate correlations with cord plasma $25(\mathrm{OH}) \mathrm{D}$ concentrations.

\section{Distinction of seasons}

Due to the tropical location of Hawai'i, its seasons are limited to winter and summer. For the purpose of this study, summer season was extended by 17 days to adjust for the 2-3 week half-life of circulating $25(\mathrm{OH}) \mathrm{D}$ that results in a 'spillover' of the $25(\mathrm{OH}) \mathrm{D}$ produced during summer season into the beginning of winter season. Thus, for analysis purposes, the summer season lasted from May 1 to November 17. The winter season was not extended due to the fast $25(\mathrm{OH}) \mathrm{D}$ synthesis and distribution into the circulation after UV exposure and lasted from November 18 to April 30. Only one cord blood sample was collected in the 'spill-over' period Nov 1-17 (from a Pacific Islander) and removing that data point from that collection led to trivial and entirely insignificant changes of all findings. Thus, all 100 data points were used for analysis.

\section{Biochemical analysis}

Cord blood samples were centrifuged and plasma aliquots were kept at $-80{ }^{\circ} \mathrm{C}$ until use. Duplicate 25(OH)D levels were measured using a commercial enzyme immunoassay kit (Immunodiagnostic Systems, Inc Cat no AC-57F1, Scottsdale, AZ) following manufacturer's instructions. The inter-assay coefficient of variation was $9.9 \%$ at mean concentrations of $31.9 \mathrm{ng} / \mathrm{mL}$. This assay was compared to the gold standard HPLC method [29] and validated by participation in quality assurance programs organized by the Vitamin D External Quality Assessment Scheme (DEQAS, London, UK) and the US National Institute of Standards and Technologies (NIST, Gaithersuburg, MD).

Vitamin D deficiency, insufficiency and sufficiency was defined as traditionally recommended in the literature and currently applied using cut-offs (traditional cut-offs, TC) of $<20 \mathrm{ng} / \mathrm{mL}, 20-30 \mathrm{ng} / \mathrm{mL}$, and $>30 \mathrm{ng} / \mathrm{mL}$, respectively [30-37]. These definitions also concur with recommendations from the 2011 Endocrine Society's Practice Guidelines, which define vitamin D deficiency and insufficiency cutoffs as $<20 \mathrm{ng} / \mathrm{ml}$ and $21-29 \mathrm{ng} / \mathrm{ml}$, respectively [38]. To convert $\mathrm{ng} / \mathrm{mL}$ to $\mathrm{nmol} / \mathrm{L}$, multiply $\mathrm{ng} / \mathrm{mL}$ by 2.5 .

\section{Grouping of ethnicities}

The 17 reported ethnicities were condensed into 6 groups to allow better inter-ethnic evaluations: Caucasian (white, non-Hispanic), African American (black, non-Hispanic), Hispanic (includes Spanish), Asians (Japanese, Chinese, Korean, Filipino, other Asian), Pacific Islander (Hawaiian, Samoan, Tongan, Micronesian, Chamorro, Cook Islander), and Other (Indian, American Indian, unknown). Participants were assigned to one of these 6 groups if they possessed combined $50 \%$ or more ethnic makeup present in that group. 


\section{Statistical evaluations}

The SAS 9.3 statistical software (SAS Institute, Cary, NC) was used for all analyses. The GLM procedure was used to assess the effects of ethnicity, season (summer vs. winter), and the ethnicity by season interaction on $25(\mathrm{OH}) \mathrm{D}$ concentrations. The Tukey-Kramer method was used for subsequent group comparisons. Because the seasonal dichotomy may have been too broad, we also applied nonlinear regression with the NLIN procedure. We fit the model equation shown below, where $y$ is the value of 25(OH)D and $x$ the date of observation. The parameters $a, b$, and $c$ are calculated to give the best possible fit, minimizing the error $(e)$ variance.

$$
y=a+b * \sin \left(2 \pi *\left(\frac{x}{365.25}+c\right)\right)+e
$$

The parameter of primary interest is $b$, the amplitude. If statistically different from zero, it would indicate the presence of sine wave; if not, it would suggest a straight line. Because of possible differences in skin pigmentation, we stratified the sine wave models by ethnic group. Only three ethnic groups (Caucasian, Asian, and Pacific Islander) had sufficient numbers for this modeling approach. Finally, the CORR procedure was used to calculate Pearson correlations between radiation and $25(\mathrm{OH}) \mathrm{D}$ concentrations.

\section{RESULTS}

\section{Demographics}

The mean age of participants was 28 years (range 18-44 years; Table 1). All but 3 participants resided on Hawai'i (island of Oahu) for the entire duration of their pregnancy (data not shown). Other demographic characteristics are summarized in Table 1. According to the entries in the medical records recorded at the prenatal visits, participants were compliant with Vitamin D supplementation of 400 IU/day (data not shown). The ethnic diversity among our 100 subjects was very extensive (Table 1). Only half of the participants reported to be of a single ethnicity while the other half were mixtures of two $(22 \%)$, three $(17 \%)$, four $(8 \%)$, or five $(3 \%)$ ethnicities in varying combinations and degrees.

\section{5(OH)D levels}

ANOVA with cord plasma 25(OH)D concentration as the dependent variable was performed with ethnic group, season, and the ethnic group by season interaction as the independent variables. The interaction was not statistically significant $[F(5,88)=0.45, p=0.81]$ and was omitted from the model. In the revised model, ethnicity $[F(5,93)=3.36, p=0.008]$ and season $[F(1,93)=11.6, p=0.001]$ were both statistically significant. The overall mean cord plasma 25(OH)D level was $24.5 \mathrm{ng} / \mathrm{mL}(9.1-68.3 \mathrm{ng} / \mathrm{mL}$; Table 2). Mean concentrations were highest in Caucasians $(30.5 \mathrm{ng} / \mathrm{mL})$ followed by Asians $(25.1 \mathrm{ng} / \mathrm{mL})$, Hispanics $(21.5$ $\mathrm{ng} / \mathrm{mL}$ ), Pacific Islanders (20.0 ng/mL), and African Americans (19.6 ng/mL). Using the Tukey-Kramer multiple group comparison test, mean concentrations of $25(\mathrm{OH}) \mathrm{D}$ were significantly different between Caucasians and Pacific Islanders $(p=0.002)$. Other comparisons were not statistically significant.

Overall, the prevalence of deficiency $(<20 \mathrm{ng} / \mathrm{mL})$ and insufficiency $(20-30 \mathrm{ng} / \mathrm{mL})$ was $28 \%$ and $50 \%$, respectively (Table 2). Only $13 \%$ of the subjects had $25(\mathrm{OH}) \mathrm{D}$ levels between $30-36 \mathrm{ng} / \mathrm{mL}$, while $3 \%$ possessed levels between $36-40 \mathrm{ng} / \mathrm{mL}$, and just $6 \%$ had levels between 40 and $75 \mathrm{ng} / \mathrm{mL}$ (data not shown). Within ethnic groups, the prevalence of vitamin D deficiency and insufficiency was 16\% and 32\% in Caucasians, $21 \%$ and 60\% in Asians, 
$33 \%$ and $67 \%$ in Hispanics, $48 \%$ and $40 \%$ in Pacific Islanders, and 50\% and 50\% in African Americans, respectively.

\section{Vitamin D status by season}

Overall, the mean cord plasma $25(\mathrm{OH}) \mathrm{D}$ levels were $30 \%$ higher in samples collected in the summer compared to winter season ( 27.1 vs. $20.8 \mathrm{ng} / \mathrm{mL} ; p=0.001$, Table 2). Among all ethnicities (except for Hispanic which remained the same), 25(OH)D levels were higher in the summer compared to winter (highly significant in Asians; $p=0.0003$ ). Seventeen of a total of 41 samples collected in winter $(41 \%)$ were deficient and $21(51 \%)$ were insufficient. Eleven of a total of 59 samples collected in summer (19\%) were deficient and $29(49 \%)$ were insufficient.

\section{Correlations of 25(OH)D concentrations with solar radiation}

Seasonal changes in $25(\mathrm{OH}) \mathrm{D}$ concentrations were correlated with solar ground radiation readings in all subjects $(\mathrm{r}=0.43, p<0.0001)$, in Caucasians $(\mathrm{r}=0.45, p=0.05)$, in Asians $(\mathrm{r}=0.55, p=0.0001)$, but not in Pacific Islanders ( $\mathrm{r}=0.18, p=0.39$; figure 1$)$. The sine wave model was statistically significant only for the Asian group $(b=5.1, p=0.0005)$.

No correlations were observed between 25(OH)D concentrations and maternal age, income, education, gravida, baby gender, birth weight, AGPAR score, head circumference, or body length (data not shown) which is in agreement with recent findings [20].

\section{DISCUSSION}

\section{High prevalence of insufficiency}

Vitamin D insufficiency and seasonal variation in vitamin D status are commonly reported in populations living at high latitudes or in countries where purdah is observed [18, 20, $23-25,34,36,39]$, but not from individuals residing in the tropics. To our knowledge, this is the first report investigating seasonal and ethnical variation in vitamin D status in umbilical cord blood collected from apparently healthy multiethnic subjects living in the tropics. For at least one month prior to delivery, all participants resided on the island of Oahu (state of Hawai'i), a tropical location located at $21^{\circ} \mathrm{N}$ latitude where sufficient sun and UV-B radiation occurs year-round for cutaneous vitamin D synthesis. Also, in Hawai'i, pregnant women are advised to take daily prenatal vitamins containing $400 \mathrm{IU}$ vitamin D. Given these conditions favoring adequate vitamin $\mathrm{D}$ status, we unexpectedly found a high prevalence of vitamin D deficiency $(<20 \mathrm{ng} / \mathrm{mL})$ and insufficiency $(20-30 \mathrm{ng} / \mathrm{ml})$ that was particularly high in samples derived in the winter season when sun irradiance was lower and, as expected, higher in ethnicities with dark versus light skin pigmentation: in Caucasians, $16 \%$ were deficient and $32 \%$ were insufficient compared to other ethnic groups where 21-50\% deficiency and 40-67\% insufficiency was observed respectively, when the entire year was considered. These findings are in good agreement with a recent study in minority groups [36] that found a fairly high percentage (14-34\%) of vitamin D insufficiency in 6-12 yearold children despite them having mean dietary intakes of 420-450 IU/day during the summer and 430-500 IU/day during the winter. Both intakes were fairly close to the recently recommended dietary intake from the Endocrine Society's Clinical Practice Guideline of 600 IU/day [38]. Our findings are also in agreement the vitamin D deficiency observed in 50\% of mothers and $65 \%$ of their newborns at delivery despite the mother's daily ingestion of approximately $600 \mathrm{IU} /$ day -receiving $400 \mathrm{IU}$ from prenatal supplements and $200 \mathrm{IU}$ from the consumption of two glasses of milk [40].

The need to consider higher vitamin D dosing particularly during pregnancy is highlighted by two supplementation trials. In the first USA based trial, only $50 \%$ of mothers 
supplementing with $400 \mathrm{IU} /$ day vitamin D achieved circulating 25(OH)D levels of $232 \mathrm{ng} /$ $\mathrm{mL}$ at delivery [34], a level needed in order for cord blood to reach $25(\mathrm{OH})$ levels of $20 \mathrm{ng} /$ $\mathrm{mL}$ [17]. Moreover, approximately $60 \%$ of the infants born to these mothers had $25(\mathrm{OH}) \mathrm{D}$ levels considered vitamin D insufficient. For neonates of mothers supplementing with 2,000 IU/day, approximately $40 \%$ had $25(\mathrm{OH}) \mathrm{D}$ levels considered less than sufficient. In the second trial, 160 pregnant minority women in the UK supplementing with 800-1,600 IU vitamin $\mathrm{D} /$ day during pregnancy were only able to increase $25(\mathrm{OH}) \mathrm{D}$ levels from approximately $8 \mathrm{ng} / \mathrm{mL}$ at baseline to $11 \mathrm{ng} / \mathrm{mL}$ at delivery.

While several studies have reported similar $25(\mathrm{OH}) \mathrm{D}$ concentrations in maternal and cord blood [18-20], one study found maternal concentrations to be lower (by approximately 4.8 $\mathrm{ng} / \mathrm{mL}$ ) than in cord blood [41], while two other studies reported the opposite [18, 28]. If we presume maternal blood $25(\mathrm{OH}) \mathrm{D}$ concentrations are $4.8 \mathrm{ng} / \mathrm{mL}$ lower than in cord blood, the prevalence of vitamin D deficiency plus insufficiency in our adult population using TC would worsen (61\% plus $30 \%$ (data not shown) versus the current $28 \%$ plus $50 \%$ ).

Alternatively, if we presume maternal blood 25(OH)D concentrations are $4.8 \mathrm{ng} / \mathrm{mL}$ higher than in cord blood, the prevalence of vitamin D deficiency plus insufficiency in our adult population, despite improving somewhat (11\% plus 50\%, data not shown), would still warrant great concern. In either scenario, the vitamin D status of both mother and newborn would still be alarmingly low because, as explained below, cord blood reflects a mixture from both mother and fetus.

\section{Use of cord blood}

Umbilical cord blood represents a mixture of maternal and fetal blood (presumably 1:1) as the umbilical vein supplies the fetus with nutrient-rich blood from the mother after it has crossed the placenta barrier at the same time the two umbilical arteries transport nutrientdepleted blood from the fetus back to the placenta. Therefore, unless blood is exclusively collected from the umbilical vein or arteries [42], 25(OH)D concentrations measured from umbilical cord blood reflect contributions from the maternal blood supply crossing the placental barrier together with those from the neonate.

For our study, only healthy full-term newborn infants born to healthy mothers were included. However, given that maternal vitamin D deficiency has been shown to increase the risk of preeclampsia, possibly preterm delivery during pregnancy $[43,44]$, poor neonatal vitamin D status [45], and neonatal small-for-gestational age births [46], it is likely the actual prevalence of vitamin D deficiency and insufficiency at delivery is higher in Hawai'i than observed in our study.

The lack of correlation between 25(OH)D concentrations and maternal age and other often quoted determinants of vitamin $\mathrm{D}$ status is in agreement with studies investigating other cord blood investigations [20] and was probably due to the relative young population, the narrow age range, and low number of participants.

\section{Ethnic differences}

Racial differences have been noted as a factor for varying vitamin D concentrations and the underlying consensus is that dark pigmented individuals synthesize less vitamin $\mathrm{D}$ in the skin than their Caucasian counterparts owing to the higher content of melanin [21, 27, 47, 48]. Our findings are in excellent agreement with this consensus. In our study, significant differences in 25(OH)D levels between ethnic groups were observed with the highest levels observed in Caucasians and lowest levels observed in African Americans (Table 2). 


\section{Seasonal differences}

25(OH)D levels were significantly higher in the summer than winter season among all subjects and also within Caucasians and Asians (Figure 1) but not within Pacific Islanders, which have been due to their relatively dark skin pigmentation and/or lifestyle factors that prevent sun exposure.

\section{Correlation with sun irradiance}

Positive correlations were found between solar radiation and 25(OH)D levels among all participants and also within Caucasians and Asians (Figure 1). Solar radiation data used in this study included overall direct plus indirect solar irradiance energies (i.e. GHI). While cutaneous vitamin D synthesis depends solely on UV-B radiation in the range of 280-320 $\mathrm{nm}$ [33], GHI data can act as a reliable proxy for UV-B dose. Positive correlations between GHI and UV-B energies have been shown previously [49] and were also observed during the period of this study $(\mathrm{r}=0.54 ; \mathrm{p}<0.0001)$ using data from NREL obtained from the Baseline Measurement System in Colorado and located at 39. $7^{\circ}$ North, $105.2^{\circ}$ West, 1828.8 m AMSL which measured 280-315 nm energies (data available at http://www.nrel.gov/ midc/srrl_bms/).

GHI concentrations on Oahu were found to be much higher in the summer than winter season (Figure 1). This summer-high trend is in excellent agreement with: (i) solar UV irradiance measurements from the Hawai'i National Park (19.4 ${ }^{\circ}$ North, 1243 m AMSL) where, in $2000,700-900 \mathrm{~W} / \mathrm{m}^{2}$ were reported in the summer and $200-400 \mathrm{~W} / \mathrm{m}^{2}$ in the winter for 286.5-363.0 nm energies [50]; (ii) the UV index trends on Oahu measured by the National Weather Service with averages of 11-12 in the summer and 4-6 in the winter; and (iii) theoretical daily vitamin $\mathrm{D}$ production calculations at latitude $21^{\circ}$ estimating approximately 10 hours during the summer and 6 hours in the winter [51].

\section{Analytical issues}

The validity of vitamin $\mathrm{D}$ assays need to be demonstrated in order to have confidence in produced data and should be examined by participation in reputable quality assurance programs such as DEQAS or NIST. The $25(\mathrm{OH}) \mathrm{D}$ immunoassay employed in this study not only participated in both programs, but was also compared to an HPLC assay, the accepted gold standard procedure for 25(OH)D measurement [29]. We acknowledge the limitation of the $25(\mathrm{OH}) \mathrm{D}$ immunodiagnostic assay of having only $\geq 70 \%$ for recovery of $25(\mathrm{OH}) \mathrm{D}_{2}$. However, this is of little relevance due to the usually negligible levels of $25(\mathrm{OH}) \mathrm{D}_{2}$ in cord blood [17] and of entire irrelevance when comparing $25(\mathrm{OH}) \mathrm{D}_{2}$ between groups within this study.

\section{Dilemma of acquiring adequate vitamin D}

Over the last several decades, negative publicity surrounding sun exposure coincided with an epidemic of vitamin D deficiency and insufficiency. For this reason and based on results from this study, we recommend that circulating $25(\mathrm{OH}) \mathrm{D}$ levels be monitored regularly, particularly during pregnancy and lactation. This should be followed by personalized dosing of sun exposure and/or vitamin D supplements in order to attain circulating $25(\mathrm{OH}) \mathrm{D}$ concentrations that will assure optimal health for both mother and newborn during the most critical period of life [12, 52]. The 2011 Endocrine Society's Practice Guidelines suggests that pregnant and lactating women ingest a minimum of $600 \mathrm{IU}$ vitamin D per day, $200 \mathrm{IU} / \mathrm{d}$ higher than the amount currently available in prenatal supplements. The society also recognizes that maintenance of $25(\mathrm{OH}) \mathrm{D}$ blood levels above the level deemed sufficient (30 $\mathrm{ng} / \mathrm{ml}$ ) may require vitamin D dosing of at least 1,500-2,000 IU/day [38]. 
Limitations of our study include missing data on confounders such as sun exposure, clothing worn, sunscreen use, dietary and supplement intake (aside from the prenatal intake of daily $400 \mathrm{IU}$ vitamin D), and quantitative measures of skin pigmentation (e.g. by skin reflectometry). In addition, we lacked information regarding pre-pregnancy BMI and tanning booth use, albeit the latter being extremely rare on Oahu. These potential determinants may have played a role in the low prevalence of vitamin D sufficiency observed along with seasonal $25(\mathrm{OH}) \mathrm{D}$ changes. It is also possible that ethnic differences may be due to these unaccounted confounders. However, we have no reason to suspect that these factors were distributed differently among the study participants compared to the general population in Hawai'i. While our study population was relatively small $(n=100)$, the ethnic distribution of our participants was almost identical to the ethnic distribution in Hawai'i, according to the most recent 2010 census -Asian $43 \%$ vs. 44\%, Pacific Islander $25 \%$ vs. $26 \%$, Caucasian $19 \%$ vs. $25 \%$ (available at www.census.gov), which is a considerable strength over previous studies that lack generalizability. Additionally, another strength in our study is our uniquely ethnically diverse population and high proportion $(\sim 75 \%)$ of non-Caucasian individuals. This diversity not only allowed comparisons among several diverse ethnic groups (with ethnic mixtures often not observed outside of Hawai'i) but also allowed us to observe differences in $25(\mathrm{OH}) \mathrm{D}$ concentrations in these groups living at a low-latitude tropical environment favorable for cutaneous vitamin D synthesis all year round.

\section{CONCLUSION}

In conclusion, we found a high prevalence of vitamin D deficiency and insufficiency in cord blood from 100 participants living in the tropical climate of Hawai'i. Our results parallel those from others with milk [40] in that over two-thirds of our study population had vitamin $\mathrm{D}$ concentrations indicative of deficiency or insufficiency despite daily recommendations to take $400 \mathrm{IU}$ of vitamin D daily. This is of great concern, particularly for the fetus and the young child who requires this important vitamin for intestinal calcium absorption, the development of vital functions, and the protection against serious diseases. Based on results from our study, we recommend that circulating $25(\mathrm{OH}) \mathrm{D}$ concentrations be monitored regularly, particularly during pregnancy and lactation, so that personalized dosing of sun exposure and/or vitamin D supplements can be determined and ultimately lead to circulating $25(\mathrm{OH}) \mathrm{D}$ concentrations that are optimal for health.

\section{Acknowledgments}

This project was supported by grants from the National Cancer Institute P30 CA71789, the National Center for Research Resources (NCRR) S10 RR020890 and from the RMATRIX award (award No. U54RR026136) NCRR, all part of the National Institutes of Health (NIH). The content in this paper is solely the responsibility of the authors and does not necessarily represent the official views of the NIH. The authors would like to thank Thomas Giambelluca, Ryan Longman and Pat Caldwell (University of Hawaii) for their assistance in retrieving the solar radiation data and Gary Lensmeyer (University of Wisconsin) for measuring 25(OH)D levels in our quality control plasma sample by HPLC. We acknowledge NREL for the generation of the solar radiation data and making them available for this study. We thank Stephen Wilcox (NREL) for the retrieval of solar and UV data from the Baseline Measurement System in Colorado.

\section{ABBREVIATIONS}

25(OH)D 25 hydroxyvitamin D

AMSL above mean sea level

DEQAS Vitamin D External Quality Assessment Scheme

DRI dietary reference intake 


$\begin{array}{ll}\text { GHI } & \text { global horizontal irradiance } \\ \text { NIST } & \text { National Institute of Standards and Technologies } \\ \text { NREL } & \text { National Renewable Energy Laboratory } \\ \text { SPF } & \text { sun protection factor } \\ \text { TC } & \text { traditional cut-offs for circulating 25(OH)D } \\ \text { UVB } & \text { ultraviolet-B }\end{array}$

\section{REFERENCES}

1. Arnson Y, Amital H, Shoenfeld Y. Vitamin D and autoimmunity: new aetiological and therapeutic considerations. Ann Rheum Dis. 2007; 66:1137-1142. [PubMed: 17557889]

2. Cantorna MT, Zhu Y, Froicu M, Wittke A. Vitamin D status, 1,25-dihydroxyvitamin D3, and the immune system. Am J Clin Nutr. 2004; 80:1717S-1720S. [PubMed: 15585793]

3. Gandini S, Boniol M, Haukka J, Byrnes G, Cox B, Sneyd MJ, Mullie P, Autier P. Meta-analysis of observational studies of serum 25-hydroxyvitamin D levels and colorectal, breast and prostate cancer and colorectal adenoma. Int J Cancer. 2011; 128:1414-1424. [PubMed: 20473927]

4. Pappa HM, Gordon CM, Saslowsky TM, Zholudev A, Horr B, Shih MC, Grand RJ. Vitamin D status in children and young adults with inflammatory bowel disease. Pediatrics. 2006; 118:19501961. [PubMed: 17079566]

5. Park E. The etiology of rickets. Physiol Rev. 1923; 3:106-119.

6. Urashima M, Segawa T, Okazaki M, Kurihara M, Wada Y, Ida H. Randomized trial of vitamin D supplementation to prevent seasonal influenza A in schoolchildren. Am J Clin Nutr. 2010; 91:12551260. [PubMed: 20219962]

7. Wang L, Manson JE, Song Y, Sesso HD. Systematic review: Vitamin D and calcium supplementation in prevention of cardiovascular events. Ann Intern Med. 2010; 152:315-323. [PubMed: 20194238]

8. Schottker B, Haug U, Schomburg L, Kohrle J, Perna L, Muller H, Holleczek B, Brenner H. Strong associations of 25-hydroxyvitamin D concentrations with all-cause, cardiovascular, cancer, and respiratory disease mortality in a large cohort study. Am J Clin Nutr. 2013; 97:782-793. [PubMed: 23446902]

9. Holmes VA, Barnes MS, Alexander HD, McFaul P, Wallace JM. Vitamin D deficiency and insufficiency in pregnant women: a longitudinal study. Br J Nutr. 2009; 102:876-881. [PubMed: 19331703]

10. Belderbos ME, Houben ML, Wilbrink B, Lentjes E, Bloemen EM, Kimpen JL, Rovers M, Bont L. Cord blood vitamin D deficiency is associated with respiratory syncytial virus bronchiolitis. Pediatrics. 2011; 127:e1513-1520. [PubMed: 21555499]

11. Camargo C, Rifas-Shiman S, Litonjua A, Rich-Edwards J, Weiss S, Gold D, Gillman M. Prospective study of maternal intake of vitamin D during pregnancy and risk of wheezing illnesses in children at age 2 years. J Allergy Clin Immunol. 2006; 117:721-722.

12. Cannell JJ. Autism and vitamin D. Med Hypotheses. 2008; 70:750-759. [PubMed: 17920208]

13. McGrath J. Hypothesis: is low prenatal vitamin D a risk-modifying factor for schizophrenia? Schizophr Res. 1999; 40:173-177. [PubMed: 10638855]

14. Merewood A, Mehta SD, Chen TC, Bauchner H, Holick MF. Association between vitamin D deficiency and primary cesarean section. J Clin Endocrinol Metab. 2009; 94:940-945. [PubMed: 19106272]

15. Stene LC, Joner G. Use of cod liver oil during the first year of life is associated with lower risk of childhood-onset type 1 diabetes: a large, population-based, case-control study. Am J Clin Nutr. 2003; 78:1128-1134. [PubMed: 14668274]

16. Stevens MC, Fein DH, Waterhouse LH. Season of birth effects in autism. J Clin Exp Neuropsychol. 2000; 22:399-407. [PubMed: 10855047] 
17. Hollis BW, Pittard WB 3rd. Evaluation of the total fetomaternal vitamin D relationships at term: evidence for racial differences. J Clin Endocrinol Metab. 1984; 59:652-657. [PubMed: 6090493]

18. Bodnar LM, Simhan HN, Powers RW, Frank MP, Cooperstein E, Roberts JM. High prevalence of vitamin D insufficiency in black and white pregnant women residing in the northern United States and their neonates. J Nutr. 2007; 137:447-452. [PubMed: 17237325]

19. Dijkstra SH, van Beek A, Janssen JW, de Vleeschouwer LH, Huysman WA, van den Akker EL. High prevalence of vitamin D deficiency in newborn infants of high-risk mothers. Arch Dis Child. 2007; 92:750-753. [PubMed: 17715438]

20. Dror DK, King JC, Durand DJ, Allen LH. Association of modifiable and nonmodifiable factors with vitamin D status in pregnant women and neonates in Oakland, CA. J Am Diet Assoc. 2011; 111:111-116. [PubMed: 21185972]

21. Nesby-O'Dell S, Scanlon KS, Cogswell ME, Gillespie C, Hollis BW, Looker AC, Allen C, Doughertly C, Gunter EW, Bowman BA. Hypovitaminosis D prevalence and determinants among African American and white women of reproductive age: third National Health and Nutrition Examination Survey, 1988-1994. Am J Clin Nutr. 2002; 76:187-192. [PubMed: 12081833]

22. Pal BR, Marshall T, James C, Shaw NJ. Distribution analysis of vitamin D highlights differences in population subgroups: preliminary observations from a pilot study in UK adults. J Endocrinol. 2003; 179:119-129. [PubMed: 14529572]

23. Harris SS, Dawson-Hughes B. Seasonal changes in plasma 25-hydroxyvitamin D concentrations of young American black and white women. Am J Clin Nutr. Jun.1998 67:1232-1236. [PubMed: 9625098]

24. Newhook LA, Sloka S, Grant M, Randell E, Kovacs CS, Twells LK. Vitamin D insufficiency common in newborns, children and pregnant women living in Newfoundland and Labrador, Canada. Matern Child Nutr. 2009; 5:186-191. [PubMed: 19292753]

25. Sloka S, Stokes J, Randell E, Newhook LA. Seasonal variation of maternal serum vitamin D in Newfoundland and Labrador. J Obstet Gynaecol Can. 2009; 31:313-321. [PubMed: 19497150]

26. Webb AR, Kline L, Holick MF. Influence of season and latitude on the cutaneous synthesis of vitamin D3: exposure to winter sunlight in Boston and Edmonton will not promote vitamin D3 synthesis in human skin. J Clin Endocrinol Metab. 1988; 67:373-378. [PubMed: 2839537]

27. Camargo CA Jr. Ingham T, Wickens K, Thadhani RI, Silvers KM, Epton MJ, Town GI, Espinola JA, Crane J. Vitamin D status of newborns in New Zealand. Br J Nutr. 2010; 104:1051-1057. [PubMed: 20426893]

28. Sachan A, Gupta R, Das V, Agarwal A, Awasthi PK, Bhatia V. High prevalence of vitamin D deficiency among pregnant women and their newborns in northern India. Am J Clin Nutr. 2005; 81:1060-1064. [PubMed: 15883429]

29. Lensmeyer GL, Wiebe DA, Binkley N, Drezner MK. HPLC method for 25-hydroxyvitamin D measurement: comparison with contemporary assays. Clin Chem. 2006; 52:1120-1126. [PubMed: 16574756]

30. Bischoff-Ferrari HA, Giovannucci E, Willett WC, Dietrich T, Dawson-Hughes B. Estimation of optimal serum concentrations of 25-hydroxyvitamin D for multiple health outcomes. Am J Clin Nutr. 2006; 84:18-28. [PubMed: 16825677]

31. Dawson-Hughes B, Heaney RP, Holick MF, Lips P, Meunier PJ, Vieth R. Estimates of optimal vitamin D status. Osteoporos Int. 2005; 16:713-716. [PubMed: 15776217]

32. Holick MF. High prevalence of vitamin D inadequacy and implications for health. Mayo Clin Proc. 2006; 81:353-373. [PubMed: 16529140]

33. Holick MF. Vitamin D deficiency. N Engl J Med. 2007; 357:266-281. [PubMed: 17634462]

34. Hollis BW, Johnson D, Hulsey TC, Ebeling M, Wagner CL. Vitamin D supplementation during pregnancy: double-blind, randomized clinical trial of safety and effectiveness. J Bone Miner Res. 2011; 26:2341-2357. [PubMed: 21706518]

35. Malabanan A, Veronikis IE, Holick MF. Redefining vitamin D insufficiency. Lancet. 1998; 351:805-806. [PubMed: 9519960]

36. Rajakumar K, Holick MF, Jeong K, Moore CG, Chen TC, Olabopo F, Haralam MA, Nucci A, Thomas SB, Greenspan SL. Impact of season and diet on vitamin D status of African American and Caucasian children. Clin Pediatr (Phila). 2011; 50:493-502. [PubMed: 21565884] 
37. Thomas MK, Lloyd-Jones DM, Thadhani RI, Shaw AC, Deraska DJ, Kitch BT, Vamvakas EC, Dick IM, Prince RL, Finkelstein JS. Hypovitaminosis D in medical inpatients. N Engl J Med. 1998; 338:777-783. [PubMed: 9504937]

38. Holick MF, Binkley NC, Bischoff-Ferrari HA, Gordon CM, Hanley DA, Heaney RP, Murad MH, Weaver CM. Evaluation, treatment, and prevention of vitamin D deficiency: an Endocrine Society clinical practice guideline. J Clin Endocrinol Metab. 2011; 96:1911-1930. [PubMed: 21646368]

39. Lim U, Freedman DM, Hollis BW, Horst RL, Purdue MP, Chatterjee N, Weinstein SJ, Morton LM, Schatzkin A, Virtamo J, Linet MS, Hartge P, Albanes D. A prospective investigation of serum 25-hydroxyvitamin D and risk of lymphoid cancers. Int J Cancer. 2009; 124:979-986. [PubMed: 19035445]

40. Lee JM, Smith JR, Philipp BL, Chen TC, Mathieu J, Holick MF. Vitamin D deficiency in a healthy group of mothers and newborn infants. Clin Pediatr (Phila). 2007; 46:42-44. [PubMed: 17164508]

41. Nicolaidou P, Hatzistamatiou Z, Papadopoulou A, Kaleyias J, Floropoulou E, Lagona E, Tsagris V, Costalos C, Antsaklis A. Low vitamin D status in mother-newborn pairs in Greece. Calcif Tissue Int. 2006; 78:337-342. [PubMed: 16830197]

42. Matsuzaki M, Haruna M, Hasumi Y, Sekine K, Tanizaki T, Watanabe E, Murashima S. Ubiquinol-10 and ubiquinone-10 levels in umbilical cord blood of healthy foetuses and the venous blood of their mothers. Free Radic Res. 2010; 44:1338-1344. [PubMed: 20815779]

43. Baker AM, Haeri S, Camargo CA Jr. Espinola JA, Stuebe AM. A nested case-control study of midgestation vitamin D deficiency and risk of severe preeclampsia. J Clin Endocrinol Metab. 2010; 95:5105-5109. [PubMed: 20719829]

44. Evans KN, Bulmer JN, Kilby MD, Hewison M. Vitamin D and placental-decidual function. J Soc Gynecol Investig. 2004; 11:263-271.

45. Bodnar LM, Catov JM, Simhan HN, Holick MF, Powers RW, Roberts JM. Maternal vitamin D deficiency increases the risk of preeclampsia. J Clin Endocrinol Metab. 2007; 92:3517-3522. [PubMed: 17535985]

46. Bodnar LM, Catov JM, Zmuda JM, Cooper ME, Parrott MS, Roberts JM, Marazita ML, Simhan HN. Maternal serum 25-hydroxyvitamin D concentrations are associated with small-forgestational age births in white women. J Nutr. 2010; 140:999-1006. [PubMed: 20200114]

47. Gilchrest BA. Sun exposure and vitamin D sufficiency. Am J Clin Nutr. 2008; 88:570S-577S. [PubMed: 18689404]

48. Lawson M, Thomas M. Vitamin D concentrations in Asian children aged 2 years living in England: population survey. BMJ. 1999; 318:28. [PubMed: 9872879]

49. Kudish A, Evseev E. Statistical relationships between solar UVB and UVA radiation and global radiation measurements at two sites in Israel. I J Climatol. 2000; 20:759-770.

50. Kimlin MG, Schallhorn KA. Estimations of the human 'vitamin D' UV exposure in the USA. Photochem Photobiol Sci. 2004; 3:1067-1070. [PubMed: 15570398]

51. Engelsen O, Brustad M, Aksnes L, Lund E. Daily duration of vitamin D synthesis in human skin with relation to latitude, total ozone, altitude, ground cover, aerosols and cloud thickness. Photochem Photobiol. 2005; 81:1287-1290. [PubMed: 16354110]

52. Wagner CL, Howard C, Hulsey TC, Lawrence RA, Taylor SN, Will H, Ebeling M, Hutson J, Hollis BW. Circulating 25-hydroxyvitamin d levels in fully breastfed infants on oral vitamin d supplementation. Int J Endocrinol. 2010; 2010:235035. [PubMed: 20049156] 


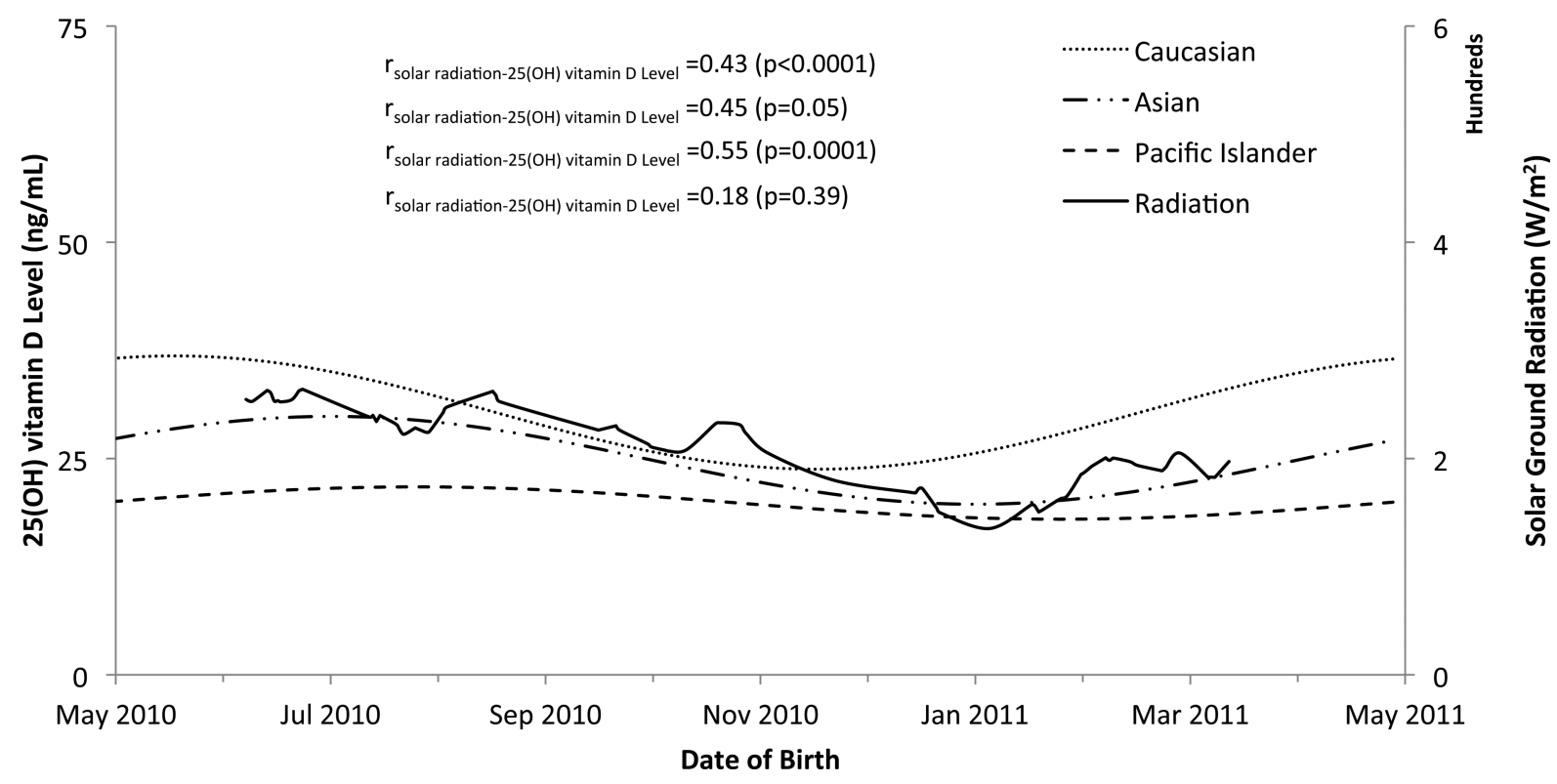

Figure 1.

25(OH)D levels and solar ground radiation over time in Caucasians $(n=19)$, Asians $(n=43)$ and Pacific Islanders $(n=25)$. Curves were generated by a sine wave model. 
Table 1

Demographic characteristics of participants

\begin{tabular}{|c|c|}
\hline Characteristic & Mean (SD) \\
\hline Mother's age, y & $28.3(6.2)$ \\
\hline Baby's birth weight, $g$ & $3411.6(464.3)$ \\
\hline Baby's head circumference, $\mathrm{cm}$ & $34.7(1.5)$ \\
\hline Baby's length, $\mathrm{cm}$ & $51.5(2.1)$ \\
\hline Gravida & $3.0(2.0)$ \\
\hline Parity & $1.0(1.0)$ \\
\hline APGAR at $1 \mathrm{~min}$, score & $8.0(1.0)$ \\
\hline APGAR at $5 \mathrm{~min}$, score & $9.0(0)$ \\
\hline Mother's Ethnicity, $\mathbf{n}$ (\% within subgroup) & Single ethnicity \\
\hline Total & $50(100 \%)$ \\
\hline Caucasian (white, non-Hispanic) & $6(12 \%)$ \\
\hline Asian (Japanese, Chinese, Korean, Filipino, other Asians) & $26(52 \%)$ \\
\hline Pacific Islander (Hawaiian, Samoan, Tongan, Micronesian, Chamorro, Cook Islander) & $15(30 \%)$ \\
\hline Hispanic (includes Spanish) & $3(6 \%)$ \\
\hline African American (Black, non-Hispanic) & $0(0 \%)$ \\
\hline Other (Indian, American Indian unknown) & $0(0 \%)$ \\
\hline 2 or more ethnicities & $50(100 \%)$ \\
\hline 2 ethnicities & $22(44 \%)$ \\
\hline 3 ethnicities & $17(34 \%)$ \\
\hline 4 ethnicities & $8(16 \%)$ \\
\hline 5 ethnicities & $3(6 \%)$ \\
\hline 6 ethnicities & $0(0 \%)$ \\
\hline \multicolumn{2}{|l|}{ Education, $\mathbf{n}$} \\
\hline$<$ High school & 9 \\
\hline zHigh school & 91 \\
\hline \multicolumn{2}{|l|}{ Income, $\mathbf{n}$} \\
\hline$\leq \$ 50,000$ & 46 \\
\hline$>\$ 50,000$ & 36 \\
\hline not stated & 18 \\
\hline \multicolumn{2}{|l|}{ Years lived in Hawai'i, $n$} \\
\hline$<1$ year & 3 \\
\hline $2-5$ years & 19 \\
\hline $6-10$ years & 16 \\
\hline $11+$ years & 62 \\
\hline \multicolumn{2}{|l|}{ Baby gender, $\mathbf{n}$} \\
\hline Male & 62 \\
\hline Female & 38 \\
\hline
\end{tabular}

$\mathrm{n}=$ number of subjects; also $\%$ since total number is 100 
Table 2

25(OH)D levels and prevalence of deficiency, insufficiency, and sufficiency ${ }^{*}$

\begin{tabular}{|c|c|c|c|c|c|c|}
\hline & $\mathbf{n}$ & $\operatorname{Mean}(\mathrm{SD})(\mathrm{ng} / \mathrm{mL})$ & Range (ng/mL) & Deficient $(<20 \mathrm{ng} / \mathrm{mL})$ & Insufficient $(20-30 \mathrm{ng} / \mathrm{mL})$ & Sufficient $(>30 \mathrm{ng} / \mathrm{mL}$ ) \\
\hline All year all subjects & 100 & $24.5(9.0)$ & $9.1-68.3$ & $28 \%$ & $50 \%$ & $22 \%$ \\
\hline Summer $^{a}$ all subjects ${ }^{b}$ & 59 & $27.1(9.8)$ & $11.2-68.3$ & $19 \%$ & $49 \%$ & $32 \%$ \\
\hline Winter ${ }^{a}$ all subjects $b$ & 41 & $20.8(6.3)$ & $9.1-41.0$ & $41 \%$ & $51 \%$ & $7 \%$ \\
\hline \multicolumn{7}{|l|}{ All year ${ }^{c}$} \\
\hline Caucasian $d, e$ & 19 & $30.5(11.8)$ & $12.1-68.3$ & $16 \%$ & $32 \%$ & $53 \%$ \\
\hline $\operatorname{Asian}^{d f} f$ & 43 & $25.1(7.9)$ & $9.1-44.4$ & $21 \%$ & $60 \%$ & $19 \%$ \\
\hline Pacific Islander ${ }^{e f}$ & 25 & $20.0(7.5)$ & $9.2-40.5$ & $48 \%$ & $40 \%$ & $12 \%$ \\
\hline Hispanic & 3 & $21.5(2.0)$ & $19.6-23.5$ & $33 \%$ & $67 \%$ & $0 \%$ \\
\hline African American & 2 & $19.6(3.0)$ & $17.5-21.7$ & $50 \%$ & $50 \%$ & $0 \%$ \\
\hline other & 8 & $23.7(6.4)$ & $13.7-34.2$ & $25 \%$ & $63 \%$ & $13 \%$ \\
\hline \multicolumn{7}{|l|}{ Summer $^{a}$} \\
\hline Caucasian & 14 & $31.5(12.8)$ & $12.1-68.3$ & $14 \%$ & $29 \%$ & $57 \%$ \\
\hline $\operatorname{Asian}^{g}$ & 25 & $28.6(7.4)$ & $17.5-44.4$ & $4 \%$ & $68 \%$ & $28 \%$ \\
\hline Pacific Islander & 15 & $21.2(8.7)$ & $11.2-40.5$ & $47 \%$ & $33 \%$ & $20 \%$ \\
\hline Hispanic & 1 & & & $0 \%$ & $100 \%$ & $0 \%$ \\
\hline African American & 1 & & & $0 \%$ & $100 \%$ & $0 \%$ \\
\hline other & 3 & $27.0(7.7)$ & $18.9-34.2$ & $33 \%$ & $33 \%$ & $33 \%$ \\
\hline \multicolumn{7}{|l|}{ Winter $^{a}$} \\
\hline Caucasian & 5 & $27.7(8.8)$ & $18.9-41.0$ & $20 \%$ & $40 \%$ & $40 \%$ \\
\hline $\operatorname{Asian}^{g}$ & 18 & $20.2(5.8)$ & $9.1-31.2$ & $44 \%$ & $50 \%$ & $6 \%$ \\
\hline Pacific Islander & 10 & $18.1(5.3)$ & $9.2-25.0$ & $50 \%$ & $50 \%$ & $0 \%$ \\
\hline Hispanic & 2 & $21.5(2.8)$ & $19.6-23.5$ & $50 \%$ & $50 \%$ & $0 \%$ \\
\hline African American & 1 & & & $100 \%$ & $0 \%$ & $0 \%$ \\
\hline other & 5 & $21.8(5.5)$ & $13.7-28.2$ & $20 \%$ & $80 \%$ & $0 \%$ \\
\hline
\end{tabular}

To convert $\mathrm{ng} / \mathrm{mL}$ to $\mathrm{nmol} / \mathrm{L}$, multiply $\mathrm{ng} / \mathrm{mL}$ by 2.5

If no superscript is shown then the difference in $25(\mathrm{OH}) \mathrm{D}$ concentrations is not significant

Sum of percentage can deviate from 100 due to rounding

based on traditionally recommended cut-offs used in the literature (see Methods)

${ }^{a}$ Summer= May 1 to November 17, Winter= November 18 to April 30 (removing data obtained from 1 cord blood sample collected in the period of Nov 1-17 (from a Pacific Islander) led to trivial and entirely insignificant changes of all findings)

$b$

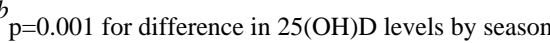

$c_{\mathrm{p}=0.008 \text { for difference between all ethnicities }}$

$d_{\mathrm{p}=0.05 \text { for difference between Caucasians and Asians }}$

J Am Coll Nutr. Author manuscript; available in PMC 2014 April 10. 


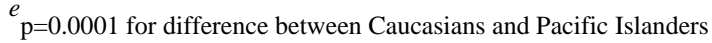

$f_{\mathrm{p}=0.01 \text { for difference between Pacific Islanders and Asians }}$

$g_{\mathrm{p}=0.0003 \text { for difference between Summer and Winter in Asians }}$ 